\title{
DOES COOPERATION REDUCE SERVICE DELIVERY COSTS? EVIDENCE FROM RESIDENTIAL SOLID WASTE SERVICES
}

\author{
Germà Bel, Universitat de Barcelona \& Cornell University \\ Xavier Fageda, Universitat de Barcelona \& Barcelona Graduate School of Economics \\ Melania Mur, Universidad de Zaragoza
}

Acknowledgments: We are grateful to comments received when this paper was presented at the First Barcelona Workshop on Public-Private Partnerships (Barcelona) and the XIX Encuentro de Economía Pública (Santiago de Compostela). Comments and suggestions received from Trevor Brown have been extremely useful. We have benefited as well from comments and suggestions by three anonymous referees.

Funding: This work was supported by the Fundación Economía Aragonesa, the Spanish Government (projects ECO2009-06946 and ECO2012-38004), and the Regional Government of Catalonia (project SGR2009-1066). Germà Bel acknowledges as well support from ICREAAcademia.

\section{Permanent contact data:}

Germà Bel (corresponding author). gbel@ub.edu Department of Economic Policy and GiMIREA. Universitat de Barcelona. Av. Diagonal, 690. 08034 Barcelona (Spain)

Xavier Fageda. xfagedal@ub.edu Department of Economic Policy and GiM-IREA. Universitat de Barcelona. Av. Diagonal, 690. 08034 Barcelona (Spain)

Melania Mur. mmur@unizar.es Departament of Economic Structure and History and Public Economics. Escuela Universitaria de Estudios Empresariales. Universidad de Zaragoza. Plaza de la Constitución s/n. 22001 Huesca, Spain 


\title{
DOES COOPERATION REDUCE SERVICE DELIVERY COSTS? EVIDENCE FROM RESIDENTIAL SOLID WASTE SERVICES
}

\begin{abstract}
The main objective of this work is to examine whether small municipalities can reduce costs through cooperation and delegation. We first examine factors explaining the decision of municipalities to cooperate and delegate service delivery responsibility, in this case residential solid waste services, to another government. Furthermore, we estimate the impact of cooperation on the costs of providing residential solid waste services. The empirical analysis is done using a sample of small Spanish municipalities. Results of the empirical analysis suggest that cooperation is a pragmatic choice for municipalities with a sub-optimal size: municipalities that cooperate by delegating face lower costs for residential solid waste services than those that do not. Furthermore, we find that cooperation allows municipalities to save costs once we control for the form of production and other factors explaining costs.
\end{abstract}

Keywords: Privatization, cooperation, costs, solid waste.

JEL codes: H4, H76, 132, L33

\section{Introduction}

Municipalities do not often coincide with the optimal scale for the delivery of services, and this mismatch can constrain decisions regarding how these services are to be provided. One means of reorganizing services in order to obtain returns to scale ${ }^{1}$ (economies of scale hereafter) is via the consolidation of governments, therefore by merging local jurisdictions. Such a process involves the merging of multiple jurisdictions, so that services are provided in an aggregate and

\footnotetext{
${ }^{1}$ Returns to scale is the generic denomination that includes economies of scale, economies of density and economies of scope (see Bel, forthcoming). These are different origins of costs savings that can eventually be obtained by means of reform of service delivery, and are associated with different characteristics of the service cost structure. From here on, we use only 'economies of scale' to avoid terminological confusion.
} 
joint form. However, this formula has met with little success in general, although it has been adopted in countries such as Holland (Bel, Dijkgraaf, Fageda and Gradus, 2010) and Switzerland (Steiner, 2003). Contrary to a number of a priori expectations, empirical evidence of the economic effects suggests that consolidation is often accompanied by cost increases. ${ }^{2}$

Alternatively, many municipalities with a suboptimal size for the production of local services resort to outsourcing in order to benefit from economies of scale (Donahue, 1989). Outsourcing can ensure cost savings because an optimal scale of production can be achieved by aggregating the production of multiple municipalities. Yet, according to recently published reviews of the empirical evidence, the results of privatization have not, in general, been as satisfactory as expected (Bel and Warner, 2008a, 2008b; Bel, Fageda and Warner, 2010). ${ }^{3}$

One important issue is that of transaction costs derived from privatization, comprising administrative costs of the contracting process, costs of monitoring the service under private production, and costs incurred from incomplete contracts. Transaction costs are relevant (Brown and Potoski, 2003a, 2003b, 2005) and can, on occasion, even exceed the cost savings associated with the exploitation of scale economies. These costs may be particularly relevant in smaller municipalities because administrative and monitoring costs are themselves subject to scale economies. Because of this, transaction costs associated with the privatization of services may be greater than any benefits it might provide (Bel and Miralles, 2003). This could be particularly the case of small municipalities, which would make private production less attractive for them.

Furthermore, as the availability of private providers is not as high in smaller municipalities as in large cities (Warner and Hefetz, 2003; Bel and Fageda, 2011), the likelihood of privatization occurring is lower (Lamothe, Lamothe and Feiock, 2008). Thus, in the least populated

\footnotetext{
2 Allers and Geertsema (2012) review most empirical studies that have analyzed the effect of consolidation on costs.

${ }^{3}$ Disappointment regarding expected results from privatization has triggered debate and scholarly analysis on reverse privatization (i.e. Hefetz and Warner, 2004).
} 
municipalities the frequency of private production is lower than it is in their more heavily populated counterparts, as has been described by Bel and Miralles (2003) and Bel (2006) for Spain, and Warner (2006) for the U.S.

Still another available reform intended to benefit from economies of scale is inter-municipal cooperation. Our main goal is to examine whether small municipalities can reduce costs through cooperation and delegation. In various European countries, local authorities have opted to work with their neighboring municipalities in inter-municipal cooperation schemes that aggregate the production of services in a number of different municipalities. Inter-municipal cooperation is now widespread in Western Europe (Hulst and van Montfort, 2007) and in Eastern and Central Europe as well (Swianiewicz, 2011). ${ }^{4}$

The same is true in Spain, whose democratization and decentralization in the 1980s 1990s sparked scholarly interest in local and intergovernmental service delivery throughout the country (Agranoff, 2010). In Spain, inter-municipal cooperation does not usually involve municipal governments contracting out the service to another government or public agency. Instead, municipal governments engage in cooperation under a joint authority (either a supra-municipal institution at the comarca/county or province level, or a single purpose agency such as Mancomunidades) in which all involved governments play a governance role. Within the context of our analysis, we frame cooperation as the decision of the municipality to delegate or transfer the responsibility of the service to the comarca/county, which is considered an inter-municipal unit (as in Agranoff, 2010, p. 107). It is important to note that inter-municipal cooperation in our context differs from the formal inter-municipal agreements typical of the United States, since in the latter case the agreement is most frequently a contract assigning responsibility for the service to just one of the municipalities (Holzer and Fry, 2011). As such, the system operated might be

\footnotetext{
${ }^{4}$ In England, however, there are few examples of horizontal cooperation among local authorities reflecting a range of historical and political factors (Kelly, 2007).
} 
seen as inter-municipal contracting. However, other types of inter-municipal cooperation exist, such as horizontal production arrangements with other governments (see Feiock and Scholz, 2010).

The factors influencing inter-municipal contracting have been extensively studied for the US: Warner and Hebdon (2001) analyze inter-municipal cooperation as one of the available alternatives to privatization. Warner and Hefetz (2002) find that smaller cities are more likely to cooperate with larger local governments to gain economies of scale. In the same way, Carr, LeRoux and Shrestha (2009) find cooperation negatively related to population. Other studies on factors influencing interlocal cooperation by LeRoux (2007) and LeRoux, Brandenburger and Pandey (2010) find that fiscal and wealth reasons do not seem to play a role, other city and regional characteristics might be influential, and social networks might be as well. In a more recent study, Shrestha and Feiock (2011) analyze interlocal agreement of different types, typically either pay-for-service (contracting to another government) or co-financing production arrangements with other local governments. They empirically study cities' service delivery mode choice and level of interlocal cooperation across multiple services, and find that interlocal cooperation is shaped by the nature and the degree of transaction risks as well as by reciprocal exchange relationships. Finally, Hefetz and Warner (2012) emphasize the role cooperation can play in services when competition is low, and Hefetz, Warner and Vigoda-Gadot (2012) find that cooperation is negatively related to population and more frequent in non-metrocore areas.

Today, local service operations in general and residential solid waste services in particular are delivered under conditions of fiscal constraint. Thus, it has become increasingly important to know how municipalities manage their local services. Empirical evidence is widely available at the local level, but very few studies have analyzed this problem for small municipalities, which typify many of Spain's regions (as in France and Italy). In our context, we define small municipalities as those below 5,000 inhabitants. In fact, this is lowest threshold established by 
Spanish legislation to define the type of services for which municipalities are responsible. Medium-size municipalities are those with populations between 5,000 and 20,000, and large municipalities are those with populations above 20,000 inhabitants.

In this paper, we first analyze factors explaining the decision of municipalities to cooperate and delegate the responsibility of residential solid waste services to the supra-municipal level. Then, we examine the determinants of the costs of providing solid waste services for a sample of small municipalities, including explanatory variables related to the form of provision municipal or supra-municipal level-, and also whether the delivery of the service is public or private. The empirical analysis takes into account the possible endogeneity bias due to the simultaneous determination of costs and cooperation.

Our main goal is to examine whether small municipalities can reduce costs through cooperation and delegation, as mentioned. We do so by controlling for the form of production. This analysis is important because modes of service delivery matter not only about what modes cities prefer and why, but also about what mode of delivery is more efficient than other.

Several studies have analyzed the impact of privatization on the costs of residential solid waste services, but the literature on the impact of inter-municipal cooperation on costs is scarce. To the best of our knowledge, this is the first empirical multivariate analysis that examines the impact of cooperation on costs, taking into account the simultaneous determination of costs and the decision to cooperate or not, and controlling for production form as well. This allows us to explicitly address whether cooperation is effective at reducing costs. In this way, we provide useful implications for policy reform of local public services. The lessons we draw from our analysis can be of particular interest to countries were regional governments exist and encompass multiple small municipalities (e.g. like counties in the United States).To carry out the empirical analysis, a survey was designed and conducted among municipalities with over 1,000 inhabitants 
in the Spanish region of Aragon, which is characterized by the small number of inhabitants in most of its municipalities.

The rest of our paper is structured as follows. In the first section, we review previous research examining the relationship between the costs of local service delivery and cooperation. In the second section, we describe the institutional framework and data relevant to our analysis. In the third section, we characterize aour empirical strategy. In the fourth section, we discuss our estimation strategies and report our results. The final section concludes the paper by identifying the implications of our empirical analysis.

\section{Cooperation and costs}

Many publicly provided goods are characterized by the existence of economies of scale, which poses a problem regarding the optimal scale for the service. Since the early seventies, economists and political scientists have analyzed the optimal size of a municipality for the provision of local services (Ostrom, Tiebout and Warren, 1961; Oates, 1972; Mirrless, 1972; Dixit, 1973). Of particular interest within our context is the work by Ostrom, Tiebout and Warren (1961, pp. 835837) on the scale problem in public organizations, and particularly the criterion of efficiency regarding the appropriated boundaries within which a public good should be provided and produced. In this way, whenever the jurisdiction's boundary does not match the optimal boundary, "the most efficient solution would require the modification of boundary conditions so as to assure a producer of public goods and services the most favorable economy of scale, as well as effective control" (p. 835). In the same direction, Donahue (1989) points out that the size of the municipality is not optimal in terms of production. Therefore, it is technically more efficient to reduce the number of companies operating in that market or even, in extreme cases where economies of scale are of great importance, to have just one company provide the entire service. 
Hence, one of the main motives for privatizing a local service could be the reduction achieved in costs through economies of scale. As the size of the smallest municipalities is not optimal for the production of certain services, outsourcing can allow an optimal scale of production to be achieved. Given that the external producer is not limited to operating in a single city (that is, within a suboptimal boundary), the production of several municipalities can be conjoined together and, as a result, cost savings can occur. For these reasons, the realization of economies of scale through outsourcing can potentially create high welfare gains. ${ }^{5}$

Since Hirsch's (1965) pioneering econometric analysis, the relationship between the costs of solid waste services and the production form has been discussed in numerous articles. Some of these works (i.e. Stevens 1978, Dubin and Navarro 1988) have laid out the main theoretical issues, testable hypotheses and technical tools that frame the analysis on the relationship between solid waste costs and production form. After almost five decades of empirical analysis on the subject, most recent and comprehensive metaliterary reviews (Bel and Warner, 2008a) and metaregression analysis (Bel, Fageda and Warner, 2010) find no systematic differences of delivery costs between private and public production.

An alternative solution to privatization can be that formulated by Ostrom, Tiebout and Warren (1961, p. 836) when they suggest that small municipalities can make use of special arrangements to act jointly to provide services when the municipal boundary is suboptimal. The aggregation of solid waste services through inter-municipal cooperation also facilitates the exploitation of economies of scale. Based on this we formulate a testable first hypothesis $\left(\mathrm{H}_{1}\right)$ :

\footnotetext{
${ }^{5}$ The lack of competition in public production results in average costs that suffer from inefficiency. The introduction of competition through auction encourages cost minimization, resulting in technical efficiency. Inter-municipal economies of scale also lead to lower average costs for the overall market winner. However, in some cases, problems of competition arise in the designation of the contract; in others, there is a trend towards the concentration of private producers (Bel and Costas, 2006; Bel and Fageda, 2011) which may result in local service privatization failing to achieve cost savings.
} 
Inter-municipal provision (cooperation) is associated with lower delivery costs than individual provision

In this regard, Bel and Costas (2006), Bel and Mur (2009) and Zafra-Rodriguez et al. (forthcoming) extend the analyses on costs of solid waste services by considering inter-municipal cooperation. The outcomes reported in Bel and Costas (2006) indicate that municipal cooperation reduces costs ${ }^{6}$ and support the hypothesis of Kodrzycki (1994) and Ballard and Warner (2000) that cost savings derived from outsourcing tend to diminish over time, and that the earlier the first recruitment experience in a municipality, the greater the competition will be and the more marked the effect on lowering service costs. Bel and Mur's (2009) results point to the existence of lower costs in the presence of cooperation, especially among smaller municipalities (less than 5,000 inhabitants). Overall, the average cost in the cooperating municipalities is $25 \%$ less than the average costs in those that do not cooperate. Zafra-Rodriguez et al. (forthcoming) also find cooperation to be associated with lower costs.

Nevertheless, inter-municipal cooperation is not exempt from problems because the cost effective choice of organization varies systematically with the attributes of transactions (Williamson, 1991). Transaction costs result from service characteristics, city characteristics, institutional design and organizational arrangements (Frederickson and Smith 2003, Feiock 2007). Sörensen (2007), in the case of Norway, and Garrone, Grilli and Rousseau (forthcoming), in the case of Italy, have studied inter-municipal cooperation. In these countries, the organizations responsible for managing municipal cooperation are multi-governmental agencies that risk aggravating principal-agent problems by increasing the distance between local government and the executive in charge of production. In addition, they weaken the incentives

\footnotetext{
${ }^{6}$ Interestingly, the outcomes reported by Bel and Costas (2006) show that cooperation is negatively related to costs for estimates of the aggregate equation and estimates that include municipalities with populations up to 10,000 and 20,000 inhabitants. By contrast, this variable is not significantly different from zero in the estimate for municipalities with a larger population (over 20,000 inhabitants).
} 
to oversee the system because of the dispersion of ownership, resulting in a reduction in the efficiency of production.

Likewise, Garrone, Grilli and Rousseau's (forthcoming) results show that the main source of inefficiency originates from the discretional nature of management. More specifically, cost efficiency is positively related to the entry of external directors to the board, and to the concentration in municipal ownership. From a political standpoint, their results indicate the importance of governance issues in the restructuring of public services.

Up until here, we have considered the distinction between collaborative provision (intermunicipal level) and individual provision (municipal level). But we need to pay attention as well to a second dimension that is important in our context, given that the comarcas/counties can make use of either public or private production. ${ }^{7}$ Recall that 'cooperation or individual' relates to the question on who provides the services, whereas 'public or private' relates to the question on who produces the service.

Within the production form dimension, there are some important issues that particularly concern small-sized municipalities. On the one hand, the availability of private providers is lower in smaller towns and in areas with lower population levels, which are precisely the places where there is potential for greater economies of scale (Warner and Hefetz, 2003; Bel and Fageda, 2008,2011 ), and this lower availability of private providers is associated with a lower likelihood of privatization (Lamothe, Lamothe and Feiock, 2008) and bigger risk of competition failure (Bel and Fageda 2011).

On the other hand, the transaction costs that small municipalities bear as a result of privatization may outweigh the potential benefits of privatization (Bel and Miralles, 2003).

\footnotetext{
${ }^{7}$ In Spain, cooperation is compatible with privatization (Bel, 2006a; Bel and Fageda, 2008). In other countries such as Netherlands (Bel, Dijkgraaf, Fageda and Gradus, 2010) and Norway (Sörensen, 2007), cooperation takes place in a situation of public production.
} 
Instead, cooperation may be subject to lower transaction costs than privatization because cooperating governments share similar objectives (Brown 2008), share similar theories of action (Kirk, Nabatchi and Balogh, 2012), and trust is higher for other governments than for private vendors (Lamothe and Lamothe, forthcoming). Therefore, with inter-municipal provision, privatization does not have the comparative advantage (with respect to inter-municipal cooperation) of allowing the municipalities the opportunity to benefit from scale economies, which they cannot do with individual provision. Furthermore, transaction costs for small municipalities are likely to be higher with private production than with public production. Based on this, we formulate a testable second hypothesis (H2): With inter-municipal provision (cooperation), public production is associated with lower costs than private production.

The factors discussed above may explain why, contrary to expectations, the frequency of privatization in towns with smaller populations is lower than in cities with medium and large populations, as shown by Bel and Miralles (2003) and Bel (2006) for Spain, and Warner (2006) for the US. Instead, small municipalities engage more frequently in inter-municipal cooperation. In spite of this, empirical analysis focusing on small municipalities is scarce in the literature. Our empirical analysis contributes to fill this gap in the literature.

\section{Institutional framework and Data}

\section{2.a Institutional framework}

Spain's National Law 7/1985 establishes that municipal governments are responsible for the provision of residential solid waste services to citizens. However, the law does not specify how these services are to be delivered. Under Spanish legal tradition, this means that municipalities are free to choose the delivery form. As such, they are free to engage in cooperation with other municipalities in order to share delivery and can choose delegate the provision of the service to different government levels. 
Several Spanish regions, including Aragon which is the subject of our analysis, have created supra-municipal jurisdictions (comarcas, still of local type) that can provide municipal services when municipalities have delegated provision. In the particular case of Aragon, the comarcas or counties- were created by the regional laws of 1993 and 1996. These laws assigned each municipality to a specific county. These laws also provided municipalities the freedom to retain the provision of a service at the municipal level, or alternatively they can transfer the responsibility to the county. In the case of delegation, members of councils from each municipality participate in governance decisions within the county government, so decisions regarding the choice of the production require the cooperative decision making of the participating municipalities. ${ }^{8}$ At any time, municipalities can revoke the delegation of service provision to the county. Nonetheless, while the service is delegated, comarcas are a strong central coordinating body, which is a requirement for effective service delivery networks according to Milward and Provan (2000).

Under this cooperative arrangement, the choice is made to use private production, public production or mixed firms for delivery. In Aragon, the region for which we conduct our exercise, several comarcas use public production to deliver solid waste, and other comarcas choose to contract out to private firms. In others regions, such as Catalonia, some comarcas make also use of mixed public-private firms for service delivery. ${ }^{9}$

Hence, inter-municipal cooperation can be used as as an alternative to privatization to exploit scale economies (Bel and Costas, 2006; Bel and Fageda, 2008), allowing the aggregation of the service at the local level and offering the possibility of realizing economies of scale with lower transaction costs. Note, however, that inter-municipal cooperation in Spain is also compatible

\footnotetext{
${ }^{8}$ Bel, Dijkgraaf, Fageda and Gradus (2010) provide information on how local supramunicial governments in Spain are formed.

${ }^{9}$ A detailed comparison of organizational formulas used for service delivery in the US and Spain can be found in Warner and Bel (2008).
} 
with the privatization of the services (Bel, 2006; Bel and Fageda, 2008). Recall that scale economies is only one among several factors that induce local public services privatization (Bel and Fageda 2007, 2009). Because of this some comarcas may prefer using private firms for service delivery even if they have already addressed economies of scale by means of a cooperative arrangement. In cases where cooperation is used for joint purchase from private firms (rather than for joint production), the transaction costs associated with the privatization process are shared by the cooperating municipalities.

\section{2.b Data}

To carry out our empirical analysis, a survey was designed and administered to municipalities with more than 1,000 inhabitants in the Spanish region of Aragon. The data refer to the year 2008 , the latest available at the time of the survey. Information regarding costs was obtained from this survey, as was that related to the means of production, ownership of the service, and the availability of a landfill in the municipality. Complete information was obtained from 85 municipalities. 66 of these 85 municipalities have less than 5000 inhabitants, while only 12 have more than 10.000 inhabitants. Thus, a very high proportion of municipalities in our sample can be considered small municipalities. An analysis of the representativeness of this sample shows that the coverage is around $80 \%$ of all the municipalities with more than 1000 inhabitants in Aragon.

Information regarding population and municipal size was provided by the National Institute of Statistics (http://www.ine.es). Information on local dispersion is published on the website of the Aragonese Institute of Statistics (http://portal.aragon.es).

The information needed to calculate the municipal financial burden, the mayor's political party, and the county president's political party was gathered from the website of the Government of Aragón (http://servicios.aragon.es/portalAALL/home.do). For fiscal and 
political variables, we have been able to obtain information for just 80 municipalities. Table 1 shows the descriptive statistics for the model's variables.

Table 2 shows the characteristics of the sample of municipalities for the different service delivery modes. Note, first and foremost, that the levels of outsourcing and cooperation in solid waste services in Aragon are very high. In fact, the level of outsourcing to private companies in the region $(66 \%)$ can be seen as representative of the Spanish market, where private firms deliver solid waste collection in around 60\% of the municipalities (Bel, 2006; Bel and Fageda 2008). On the contrary, inter-municipal cooperation is very frequent in Aragon $(88 \%$ of the municipalities in the sample). This is much higher than in the Spanish market as a whole, where around of $40 \%$ of the municipalities cooperate, percentage that grows until $52 \%$ if we take only into account municipalities between 2,000 and 10,000 inhabitants in Spain (Bel, 2006). ${ }^{10}$

\footnotetext{
${ }^{10}$ As mentioned, we drop five cases in the sample used for the estimation because we have not been able to find data for fiscal and political variables. Four of these five cases fit in the category of joint purchase from the market, while 1 of the cases fit in the category of bilateral purchase from the market. We do not expect these dropped cases to have substantial impact on the results because the category of joint purchase from the market is the more frequent in our final sample of municipalities.
} 
Table 1. Descriptive statistics of the model's variables

\begin{tabular}{|c|c|c|c|c|c|}
\hline Continuous Variables & Average & $\begin{array}{l}\text { Standard } \\
\text { Deviation }\end{array}$ & Minimum & Maximum & $\mathbf{N}$ \\
\hline $\begin{array}{c}C T E \text { (total } \\
\text { expenditures in euro) }\end{array}$ & 165488.2 & 296879 & 11970.48 & 1991663 & 85 \\
\hline $\begin{array}{l}\text { POP (Number of } \\
\text { inhabitants) }\end{array}$ & 4877.1 & 7469.5 & 871 & 51117 & 85 \\
\hline $\begin{array}{l}\text { DISP (number of } \\
\text { neighbors in the } \\
\text { municipality) }\end{array}$ & 3.4 & 5.1 & 1 & 33 & 85 \\
\hline $\begin{array}{l}\text { DEN (number of } \\
\text { inhabitants per square } \\
\text { kilometer) }\end{array}$ & 70.4 & 140.9 & 6.1 & 958.5 & 85 \\
\hline $\begin{array}{l}\text { DIST (distance to the } \\
\text { landfill in kilometers) }\end{array}$ & 34.23 & 20.4 & 0 & 76 & 85 \\
\hline $\begin{array}{l}\text { CFCRA (Index of } \\
\text { financial burden) }\end{array}$ & 0.08 & 0.09 & $1.83 \mathrm{e}-06$ & 0.57 & 80 \\
\hline \multicolumn{2}{|c|}{ Discrete variables } & $\begin{array}{c}\text { Number } \\
\text { observations } 1\end{array}$ & $\begin{array}{c}\text { Number } \\
\text { observations } 0\end{array}$ & & \\
\hline \multicolumn{2}{|l|}{$D^{\text {Delegation }}($ cooperation $=1)$} & 75 & 10 & & 85 \\
\hline \multicolumn{2}{|c|}{$D^{\text {privatization }}($ private production $=1$ ) } & 56 & 29 & & 85 \\
\hline \multicolumn{2}{|c|}{$\begin{array}{l}D^{\text {inter-municipal cooperation }} \text { (public production } \\
\text { with cooperation }=l \text { ) }\end{array}$} & 26 & 59 & & 85 \\
\hline \multicolumn{2}{|c|}{$\begin{array}{l}\text { with cooperation }=1) \\
D^{\text {joint }} \text { purchase from the market (private } \\
\text { production } \text { with cooperation }=1 \text { ) }\end{array}$} & 49 & 36 & & 85 \\
\hline \multicolumn{2}{|c|}{$D^{\text {in-house production (public production with }}$} & 3 & 82 & & 85 \\
\hline \multicolumn{2}{|c|}{$\begin{array}{l}\text { no cooperation }) \\
D^{\text {bilateral purchase from the market }}(1=\text { private }\end{array}$} & 7 & 78 & & 85 \\
\hline \multicolumn{2}{|c|}{$\begin{array}{l}\text { production with no cooperation) } \\
\left.D^{\text {Pol }} \text { (mavor right-wing }=1\right)\end{array}$} & 41 & 39 & & 80 \\
\hline \multicolumn{2}{|c|}{$\begin{array}{l}\text { chair of the county =1) } \\
\text { carty major- }\end{array}$} & 52 & 28 & & 80 \\
\hline
\end{tabular}

Source: authors' own

Table 2. Characteristics of municipalities according to the form of delivery (average values)

\begin{tabular}{|c|c|c|c|c|}
\cline { 2 - 5 } \multicolumn{1}{c|}{} & $\begin{array}{c}\text { Inter-municipal } \\
\text { cooperation } \\
(\mathbf{N = 2 6})\end{array}$ & $\begin{array}{c}\text { Joint purchase from } \\
\text { the market } \\
(\mathbf{N = 4 9 )}\end{array}$ & $\begin{array}{c}\text { In-house } \\
\text { production } \\
(\mathbf{N = 3})\end{array}$ & $\begin{array}{c}\text { Bilateral purchase } \\
\text { from the market } \\
(\mathbf{N}=7)\end{array}$ \\
\hline Total costs (CTE) & 197060.6 & 100099.6 & 748663.2 & 256007.3 \\
\hline Costs per capita & 31.7 & 33.5 & 40.04 & 47.8 \\
\hline Population (POP) & 6066.1 & 3131.8 & 17660 & 7200 \\
\hline $\begin{array}{c}\text { Density of } \\
\text { population (DEN) }\end{array}$ & 53.1 & 67.1 & 40.9 & 171.6 \\
\hline Dispersion (DISP) & 4.5 & 2.7 & 5.6 & 27.3 \\
\hline $\begin{array}{c}\text { Distance to the } \\
\text { landfill (DIST) }\end{array}$ & 26.3 & 40.6 & 13.6 & \\
\hline
\end{tabular}

Note: Data for all the variables refer to 2008. 
At the same time, it also appears that population is much higher in the municipalities that decided not to delegate the service, even though per capita costs are also higher in these municipalities. By contrast, the population is higher in those municipalities with public production than it is in those with private production. Given the choice of cooperate or not, costs per capita are higher for municipalities with private production.

Table A1 in the appendix shows data about the characteristics of the municipalities that cooperate. As expected, the population of the capital of the county is usually much higher than that of the rest of municipalities in the county. All municipalities that cooperate and are not the capital of the county have less than 5000 inhabitants and we can find several examples of municipalities with less than 2000 inhabitants. Thus, it is clear that municipalities that cooperate are characterized by a very small size. Distance to the capital of the county is generally lower than 30 kilometers, although we can find some few examples of municipalities that cooperate and that are about 40 kilometers away from the capital. Overall, it seems that the municipality needs to be located relatively close to the capital in order to transfer the responsibility of the service to the county.

\section{The empirical strategy}

In this section, we first analyze factors explaining the decision to delegate and cooperate or not, that is to say, the decision to delegate to the county the responsibility for residential solid waste services. Then, we study the determinants of the costs of providing solid waste services for a sample of small municipalities.

Regarding the decision to cooperate or not, we estimate the following equation:

$\mathrm{D}^{\text {Delegation }}=\beta_{0}+\beta_{1} C T E_{\mathrm{i}}+\beta_{2} \mathrm{POP}_{\mathrm{i}}+\beta_{3} \mathrm{DISP}_{\mathrm{i}}+\beta_{4} \mathrm{CFCRA}_{\mathrm{i}}+\beta_{5} \mathrm{D}_{\mathrm{i}}^{\mathrm{Pol}_{i}}+\beta_{8} \mathrm{D}^{\text {Municipality_county }_{i}}+\varepsilon_{\mathrm{i}}$ 
The dependent variable in this equation is a dummy variable that takes the value one for those municipalities that have chosen to delegate the responsibility of the service to the county, $\mathrm{D}^{\text {Delegation }}$. Thus, this variable takes the value one for those observations where the production form is inter-municipal cooperation or joint purchase of the market, and it takes the value zero in other cases. These are the explanatory variables included in our equation of factors explaining the decision to delegate the production of the service to the county:

1) The total costs paid for solid waste services in the municipalities of Aragon, CTE. These costs include expenditures covering collection, transport, disposal/self-disposal and treatment. With this variable, we want to test whether municipalities may choose to delegate the responsibility of the service to the county in order to save costs. If this is the case, municipalities that afford higher costs in delivering the service may choose to transfer the responsibility of the service to the supra-municipal level. Thus, we expect a positive sign in the coefficient associated to this variable.

2) Population of the municipality, $P O P$. As a proxy for output we take the population of the municipality, according to the 2008 municipal register of inhabitants. ${ }^{11}$ A negative relationship is expected between population and the decision to delegate the delivery of the service at the supra-municipal level, consistent with results in Warner and Hefetz (2002), Bel and Costas (2006), Bel and Fageda (2008), and Shrestha and Feiock (2011). A major motivation for a municipalitity to cooperate with other municipalities has to do with the economies of scale. Larger municipalities may be able to exploit scale economies by themselves, while small localities may have a suboptimal size for the production of the service.

\footnotetext{
${ }^{11} \mathrm{We}$ do not have enough data for the amount of solid wasted treated in each municipality. Using population as a proxy for waste output has been done in several studies (i.e. Kitchen, 1976; Bel and Mur, 2009), and other studies use different proxies when lacking data on waste output (Hirsch, 1965; Pier, Vernon and Wicks, 1974; Kemper and Quigley, 1976; Domberger, Meadowcroft and Thompson, 1986; Szymanski and Wilkins, 1993; Reeves and Barrow, 2000; and Dijkgraaf and Gradus 2003).
} 
3) Municipal dispersion, DISP. Controlling for costs, greater dispersion of the municipality increase the complexity of supervision by the local government. Indeed, greater dispersion makes more difficult to ensure that the service is properly provided, thus increasing transaction costs from cooperation. Transaction cost are negatively related to cooperation (Shrestha and Feiock, 2011), thus dispersion could spur the local government to maintain the provision of the service within the own jurisdiction. Thus, the expected effect of the variable of dispersion on the likelihood of cooperation is negative.

4) Index of financial burden, CFCRA. Financial conditions have been considered when analyzing the cooperation decision, as in Shrestha and Feiock (2011). A municipality's financial difficulties may constitute a decisive factor in the decision to the delegate the delivery of the service, especially in small municipalities. We built this variable as the ratio of debt costs (interest plus amortization) and current revenue ${ }^{12}$ (Chapter I to $\mathrm{V}$ of income).

5) A dummy variable that takes the value one when the political ideology of the mayor is right-wing, $D^{P o l}$. With this variable, we are aimed to show if local politicians who decide to delegate the delivery of the service can be influenced by ideological criteria. As the decision whether to cooperate should be a pragmatic decision (as it usually is the privatization decision see Bel and Fageda, 2007, 2009), the expected effect for the coefficient associated with this variable is not clear. ${ }^{13}$

6) A dummy variable that takes the value one when the mayor of the municipality is of the same party that the chair of the county, $\mathrm{D}^{\text {Municipality_county }}$. We expect that municipalities run by the same political party as that governing the county are more likely to delegate the delivery of

\footnotetext{
${ }^{12}$ In accordance with the Ley Reguladora de las Haciendas Locales, that states that the sum of depreciation plus interest on debt cannot exceed 25 per cent of the Region's current revenues.

13 Thus, we consider a mayor's party ideology to be left-wing if she belongs to the Partido Socialista Obrero Español (PSOE), Izquierda Unida (IU) or Chunta Aragonesista; and right-wing if she belongs to the Unión de Centro Democrático (UCD), Partido Popular (PP, formerly People's Alliance) or Partido Aragonés (PAR).
} 
the service to this supra-municipal entity. Thus, we expect a positive sign in the coefficient associated to this variable.

Along with the factors explaining the decision to delegate or not, we want to examine whether municipalities save costs by delegating the service to the county once we control for the form of production. It is also of interest to identify the different relationship that both private production and cooperation may have on the costs of providing the solid waste service. Ideally, this would allow us to identify the most effective way (private production or cooperation) to organize the provision of this service so as to maximize cost savings. However, we do not have enough data to provide a clear answer to the question of whether cooperation is more effective than privatization in saving costs. Still, we estimate two different cost equations in order to disentangle the impact of cooperation on costs by controlling for whether the service is delivered directly or through a contract:

$$
\begin{aligned}
C T E_{\mathrm{i}}= & \beta_{0}+\beta_{1} D_{\text {Delegation }_{i}}+\beta_{2} D_{\text {privatization }_{i}}+\beta_{3} \mathrm{POP}_{\mathrm{i}}+\beta_{4} \mathrm{DISP}_{\mathrm{i}}+\beta_{5} \mathrm{DEN}_{\mathrm{i}}+\beta_{6} \mathrm{DIST}_{\mathrm{i}}+\varepsilon_{\mathrm{i}} \\
C T E_{\mathrm{i}}= & \beta_{0}+\beta_{1} D^{\text {inter-municipal cooperation }}{ }_{i}+\beta_{2} D^{\text {joint purcharse from the market }}{ }_{i}+\beta_{3} D^{\text {in-house production }}{ }_{i}+\beta_{4} \mathrm{POP}_{\mathrm{i}}+ \\
& +\beta_{5} \mathrm{DISP}_{\mathrm{i}}+\beta_{6} \mathrm{DEN}_{\mathrm{i}}+\beta_{7} \mathrm{DIST}_{\mathrm{i}}+\varepsilon_{\mathrm{i}}
\end{aligned}
$$

The dependent variable in both cost equations $(C T E)$ represents the total costs paid for solid waste services in the municipalities of Aragon, and includes expenditure covering collection, transport, disposal/self-disposal and treatment.

In equation (2), we include as explanatory variables a dummy variable that takes the value one when the municipality chooses to delegate the responsibility of the service $\left(D^{\text {Delegation }}\right)$ and a dummy variable that takes the value one when the service in the municipality is provided by a private firm through a contract $\left(D^{\text {privatization }}\right)$. Indeed, the variable of delegation takes the value one when the production form is inter-municipal cooperation or joint purchase from the market, while it takes value zero in other cases. The variable of privatization takes the value one when 
the production form is joint or bilateral purchase from the market, and zero in other cases. With this equation, we are able to examine whether cooperation implies lower costs controlling for the form of production.

In equation (3), we include variables for the following service delivery choices: a) Dummies

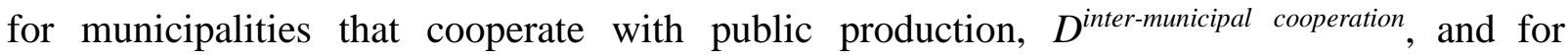
municipalities that cooperate with private production, $D^{\text {joint purcharse from the market }}$. b) Dummy for municipalities that not cooperate with public production, $D^{\text {in-house production }}$. The reference case in this regression is the alternative of not cooperating with private production (bilateral purchase from the market). With this latter equation, we can compare whether cooperation is more effective than privatization in saving costs. However, the low number of observations for some of these service delivery choices makes advisable to proceed with the estimation of the cost equation with two different estimation techniques (2SLS and OLS respectively). Note, in this regard, that we have just three municipalities in our sample that has chosen public production with no cooperation (in-house production).

The empirical literature suggests, as discussed above, that inter-municipal cooperation may be seen as an alternative (albeit compatible) to privatization for smaller municipalities with fewer potential external contractors (Warner and Hefetz, 2002, 2003; Bel and Costas 2006). Municipalities are expected to cooperate in order to reduce costs; therefore, a priori, the expected effect of the variables for municipalities that cooperate is negative. On the contrary, in the most recent and most robust empirical studies no differences between public and private production have been found. Thus, the expected effect of the form of production (public or private) is undetermined.

The focus of our analysis is on the impact of cooperation and privatization on costs. Taken this into account, we consider the following control variables in both cost equations: 
1) Population of the municipality, $P O P$. As a proxy for output we take the population of the municipality. We expect a positive relationship between population and total costs. In fact, this variable should have the greatest impact on the explanatory power of the model. Note also that this variable captures the economies of scale of individual cities.

2) Distance to the closest landfill, DIST. Total costs should be higher when distance to the landfill increases (Callan and Thomas, 2001; Bel and Costas, 2006). Thus, we expect a positive coefficient for the relationship between the landfill and the costs of the service.

3) Municipal density, DEN. Previous empirical studies frequently use the number of dwellings in relation to the area of the municipality as an explanatory variable. However, the lack of up to date figures for this variable in Aragon means we have used the number of inhabitants per square kilometer as our indicator of "population density". On the one hand, increasing population density leads to a rise in the amount of waste collected at each stop, which in principle should reduce collection costs. However, on the other hand, a higher concentration of population leads to more traffic congestion and so increased travel time could cause costs to rise. Previous results on population density have been ambiguous (Kitchen, 1976; Domberger et al., 1986; Dubin and Navarro, 1988; Callan and Thomas, 2001; Bel and Costas 2006). Therefore, the final effect of the $D E N$ variable is a priori undetermined.

4) Municipal dispersion, DISP. A large number of villages within a municipal area may increase service costs because of the greater distances involved in providing the service (Bel and Miralles, 2003; Fluvià, Rigall i Torrent and Garriga, 2008). Therefore, the DISP variable is expected to have a positive effect on costs. Note that the variables of population density and dispersion are both related to transportation costs of delivering the service. However, they are measuring different attributes of the municipality since the variable of dispersion has to do with the number of villages regardless of the amount of population of each of these villages. 


\section{Estimation and results}

There may be a simultaneous determination of costs and the decision to cooperate. In this regard, the estimation technique must take into account the potential bias due to the inclusion of endogenous explanatory variables. Indeed, the cost variable may be endogenous in the equation for factors explaining cooperation and the cooperation variable may be endogenous in the cost equation. That is to say, the decision to cooperate or not can be dependent on costs (among other factors), and costs can be dependent on the provision/production form (among other factors).

In such a case, these explanatory variables may be correlated with the error term so that one of the basic conditions to validate the ordinary least squares estimator (OLS) or a standard probit model is not met. The standard solution to the potential bias that comes from endogenous explanatory variables is to apply an instrumental variables procedure where the endogenous explanatory variable is estimated in a first step using exogenous instruments and the estimated (rather than actual) values of the endogenous variable are included in the equation of interest. ${ }^{14}$ Hence, we apply a two-state procedure in the estimation of equations (1) and (2).

Unfortunately, we are not able to apply a two-stage procedure in the estimation of equation (3) because we do not have enough instruments for the endogenous explanatory variables. The estimation of equation (3) was undertaken using the ordinary-stage least squares estimator.

The two-stage procedure in the estimation of equation (1) is as follows. First, we estimate an equation that has the total costs as the dependent variable and includes as independent variables the exogenous explanatory variables of the equation and additional instruments for the variable of costs. The additional instruments must be correlated with the instrumented variable and not correlated with the error term. We can find the instruments in equation (2); (i) Distance to the

\footnotetext{
${ }^{14}$ The instruments are variables correlated with the endogenous explanatory variable that must be exogenous (ie; not correlated with the error term).
} 
closest landfill (DIST), (ii) Municipal density $(D E N)$. In the second stage, we estimate equation (1) using a probit with instrumental variables where the values of the variable of costs are those obtained from the estimation in the first stage.

The two-stage procedure in the estimation of equation (2) is as follows. First, we estimate an equation that has the dummy variable for cooperation as the dependent variable and includes as independent variables the exogenous explanatory variables of the equation and additional instruments of the dummy variable for cooperation. Again the instruments can be found in equation (1); (i) Index of financial burden (CFCRA), (ii) A dummy variable that takes the value one when the political ideology of the mayor is right-wing $\left(D^{P o l}\right)$, (iii) A dummy variable that takes the value one when the mayor of the municipality is of the same party that the chair of the county ( $\left.\mathrm{D}^{\text {Municipality_county }}\right)$. In the second stage, we estimate equation (2) using the two-stage least squares where the values of the dummy variable of cooperation are those obtained from the estimation in the first stage.

All data for the variables used in the empirical analysis refer to 2008 . Hence, we estimate a cross-sectional model. Standard deviations of the error term were robust to any problem of heteroscedasticity by applying White standard errors, and clusters were used at the provincial level (NUTS 3) in order to take into account the possible correlation between observations for municipalities in the same province. Unfortunately, we do not have enough observations to apply clusters at the county level. If we do that, most of variables lose its statistical significance. Note that the computed Variance Inflation Factor (VIF) indicates that our cost regression does not have a problem of multicollineality. The VIF obtained in the equation of factors explaining cooperation is higher because of the correlation between the variables of population and total costs, although., this correlation does not alter the statistical significance of both variables. 
Table 3 shows the results of the equation for the factors explaining cooperation, while table 4 shows the results of the two estimated cost equations.

Table 3. Empirical results of the estimation of the determinants of cooperation (probit with instrumental variables)

\begin{tabular}{|c|c|}
\hline & Dependent variable: $\mathrm{D}^{\text {delegation }}$ \\
\hline CTE & $0.00012(1.13 \mathrm{e}-06)^{* * *}$ \\
\hline POP & $-0.0004(0.000024) * * *$ \\
\hline DISP & $-0.11(0.02)^{* * *}$ \\
\hline$\overline{C F C R A}$ & $-0.48(0.59)$ \\
\hline$D^{P o l}$ & $-0.16(0.10)$ \\
\hline$D^{\text {Municipality_county }}$ & $0.39(0.18)^{* *}$ \\
\hline CONSTANT & $0.56(0.08)$ \\
\hline $\begin{array}{c}\text { Test } \chi^{2} \text { (joint significance) } \\
\text { Log-pseudolikelihood } \\
\text { Mean VIF } \\
\text { N }\end{array}$ & $\begin{array}{l}96.81 * * * \\
-1035.38 \\
6.95 \\
80\end{array}$ \\
\hline
\end{tabular}

Note 1: *** indicates significance at $1 \%$ level; ** indicates significance at $5 \%$ level; * indicates significance at $10 \%$ level.

Note 2: In parentheses, standard errors robust to heteroscedasticity and clustered by provinces Source: authors' own

We find evidence that it is more likely that municipalities cooperate to deliver solid waste when the costs of this service are higher. Furthermore, larger and dispersed municipalities tend to cooperate less often. Finally, it is more likely that municipalities cooperate when the political party of the mayor in the municipality is the same political party that manages the county. The variables of fiscal burden and the dummy for right-wing majors are not statistically significant.

Hence, municipalities may be guided by pragmatic reasons in their decision to cooperate with other municipalities in the delivery of the service. Indeed, it seems that this policy option is aimed to reduce costs because municipalities that afford higher costs tend to delegate the responsibility of the service to the county. On the contrary, related fiscal variables do not seem to be influential, consistent with results in LeRoux (2007). Additionally, the ideological variable is not statistically significant. In this regard, a clear way for municipalities to save costs by choosing cooperation has to do with the exploitation of scale economies. This explains that larger 
municipalities tend to cooperate less often because they may achieve scale economies by themselves, consistent with results in Warner and Hefetz (2002) and Carr, LeRoux and Shrestha (2009). Finally, cooperation may be less likely when the supervision of the service is more complex (that is, when population of the municipality is more dispersed) and when the coordination with the county may be also more complex (when major and the county's chair are from a different political party), all of this is consistent with findings in Shrestha and Feiock (2011) on transaction costs and on reciprocal exchange, and results in LeRoux, Brandenburger and Pandey (2010) on social networks and cooperation.

Regarding the estimation of cost equations, total costs increase as the population rises as expected. On the other hand, costs also increase as the population density rises although the coefficient associated with this variable is positive and statistically significant only in the estimation of equation (2). We also obtain some evidence that total costs are higher as population dispersion rises. Furthermore, costs seem to be higher when the distance to the landfill increases although the coefficient associated to this variable is positive and statistically significant just in the estimation of equation (2).

Importantly, we find that cooperation may allow municipalities to save costs even when controlling for the form of production. Indeed, the dummy variable of cooperation is negative and statistically significant in the estimation of equation (2). On the contrary, the dummy variable for private production is also negative but not statistically significant. The test of equal parameters between the dummy variables for cooperation and privatization confirms the statistical difference in the size of the coefficients associated to these variables. 
Table 4. Empirical results of the estimation of the determinants of costs

\begin{tabular}{|c|c|c|}
\hline & $\begin{array}{c}\text { Dependent variable: CTE } \\
\text { - equation (2) } \\
\text { (Two-stage least squares) }\end{array}$ & $\begin{array}{c}\text { Dependent variable: CTE - } \\
\text { equation (3) } \\
\text { (Ordinary least squares) }\end{array}$ \\
\hline$D^{\text {Delegation }}$ & $-189962.3(78194.39)^{* * *}$ & - \\
\hline D $^{\text {privatization }}$ & $-11628.37(28860.53)$ & - \\
\hline$D^{\text {inter-municipal cooperation }}$ & - & $-28492.1(10110.1)^{*}$ \\
\hline$D^{\text {joint purchase from the market }}$ & - & $-4184.97(12218.04)$ \\
\hline$D^{\text {in-house production }}$ & - & $131325.8(122277.2)$ \\
\hline POP & $32.64(2.90)^{* * *}$ & $32.12(5.82)^{* *}$ \\
\hline DISP & $8582.96(1698.87)^{* * *}$ & $12343.99(2108.78)^{* *}$ \\
\hline DEN & $397.34(108.17) * * *$ & $64.53(27.69)$ \\
\hline DIST & $548.45(234.48) * * *$ & $-445.16(908.70)$ \\
\hline CONSTANT & $113275.7(110335.4)$ & $-16577.07(56516.5)$ \\
\hline $\mathbf{R}^{2}$ & 0.92 & 0.91 \\
\hline Test-F (joint significance) & $85.11 * * *$ & $34.54 * * *$ \\
\hline Mean VIF & 2.95 & 2.05 \\
\hline $\mathbf{N}$ & 80 & 80 \\
\hline Test $\mathbf{D}^{\text {delegation } \neq} \mathbf{D}^{\text {privatization }}$ & $28.74 * * *$ & - \\
\hline $\begin{array}{c}\text { Test } \\
D_{\text {cooperate }}^{\text {public-cooperate } \neq}\end{array}$ & - & $20.03^{* *}$ \\
\hline
\end{tabular}

Note 1: $* * *$ indicates significance at $1 \%$ level; $* *$ indicates significance at $5 \%$ level; * indicates significance at $10 \%$ level.

Note 2: In parentheses, standard errors robust to heteroscedasticity and clustered by provinces

Source: authors' own

In equation (3), the coefficient associated to the dummy variable for municipalities that cooperate with public production (inter-municipal cooperation) is negative and statistically significant at the $10 \%$ level. The coefficient associated to the dummy variable for municipalities that cooperate with private production (joint purchase from the market) is also negative but not statistically significant. The test of equal parameters between the dummy variables for intermunicipal cooperation and joint purchase from the market confirms the statistical difference in the size of the coefficients associated to these variables. Finally, the coefficient associated with the dummy variable for municipalities with in-house production is positive but not statistically significant. Our results indicate that the delivery choice mode that allows municipalities to save a higher amount of costs is public production with cooperation (inter-municipal cooperation). 
Thus, we find evidence that cooperation is an effective delivery choice mode for saving costs in the case of small municipalities. On the contrary, it seems that the form of production (public or private) does not have a strong relevant effect on costs. However, we must be cautious in the interpretation of the latter result because we do not have enough data to clearly disentangle the effect of cooperation and privatization on costs.

In conclusion, it seems that local governments in small municipalities may obtain further cost savings if they decide to co-operate with other municipalities in the provision of this service, while the decision to privatize the service or maintain public production seems less relevant in terms of costs.

In municipalities with small populations, there are two factors that may serve to explain why costs with private production are not necessarily lower. First, these municipalities may face difficulties in meeting the high transaction costs derived from the design and supervision of contracts with private companies. Second, it is likely that competition for the contract is not strong given the small number of companies that tender for such contracts. In fact, in many cases local monopolies may be consolidated in small municipalities (Bel and Fageda, 2011). These two factors, transaction costs and the lack of competition, may explain why the variable of private production is not statistically significant.

The other factor that can have a real impact on the potential cost savings of privatization is the exploitation of scale economies. Indeed, private companies can aggregate the output generated by several municipalities, while the output of the municipality itself (where the population is modest) may not be sufficient to minimize costs. However, our results indicate that inter-municipal cooperation, which also allows the exploitation of scale economies through the aggregation of the output of different municipalities, seems a more effective alternative than privatization to reduce costs. The fact that inter-municipal cooperation involves lower 
transaction costs and is less likely to be affected by competition problems may account for this result. Nonetheless, we must note that because we use a small sample from a very specific population we cannot claim direct generalization of our results.

Finally, one interesting issue arising from our results is why 10 municipalities chose not to cooperate in spite of the potential benefits derived from cooperation. Two factors may be crucial to explain this issue. First, the fact that those municipalities that decided not to delegate to the county tend to have larger population, so they might have less to gain from delegating the service in order to exploit scale economies. Second, municipalities whose mayor belongs to a different political party from that of the county's chairman are less prone to delegate the service to the county, and this might be influential as well, consistent with coordination problems coming from different characteristics such as ideology of participating communities (Lowery 2000, Feiock 2007). After all, cost considerations are not the sole driver of service delivery choices (see, in this regard, Bel and Fageda, 2007, 2009).

\section{Conclusion}

This article has examined the decision of small municipalities to cooperate in the delivery of residential solid waste services and the impact this decision has on the costs of providing the service. We find that the decision to cooperate is a pragmatic choice of municipalities with a sub-optimal size: the empirical evidence provides suggests that cooperation leads to lower service provision costs.

Furthermore, we have found that cooperation allows municipalities to save costs once we control for the form of production and other factors explaining costs. In this regard, our empirical analysis suggests that cooperation may be a more efficient way than privatization to save costs, although we must be cautious in the interpretation of this latter result because our data is not rich enough to disentangle the effect of privatization and cooperation on costs. The availability of 
larger samples from a less specific population of cities would be helpful to further analyze this issue.

It should be borne in mind that while there is an extensive empirical literature analyzing factors explaining privatization and the impact of privatization on cost savings, few previous studies have analyzed the motivations and consequences of the use of inter-municipal cooperation. In this way, we have been able to contribute to the literature regarding the analysis of the most efficient way of organizing the provision of the service so as to achieve the greatest cost savings.

Our findings would suggest that local governments in small municipalities can obtain greater cost savings by opting to cooperate with other municipalities in the provision of the service. However, the decision as to whether to outsource the service or to maintain public production seems less relevant in terms of costs. This last result is consistent with the most recent empirical evidence in the literature.

The potential cost savings of privatization has to do -among other factors- with the exploitation of scale economies. Private companies can aggregate the output generated by several municipalities, while the municipal output (where a population is only modest) may not be sufficient to minimize costs. However, our results show that inter-municipal cooperation, which similarly allows scale economies to be exploited by grouping the output of different municipalities, appears to be a more effective alternative than private delivery for reducing costs. The explanation for this seems to lie in the fact that inter-municipal cooperation incurs lower transaction costs and is less likely to be affected by competition failures. On this point, it is worth recalling that our analysis is done for a sample of municipalities of small dimension at a particular point of time, which precludes automatically extending our conclusion for all types of 
municipalities. In fact, large municipalities operate at optimal scale on their own, and could be less affected by competition failures when opting for private delivery without cooperation.

Our results have interesting implications for public policy. Among them, we think worth emphasizing the potential that inter-municipal cooperation appears to offer in realizing economies of scale and, thus, in reducing costs. In this regard, policies establishing incentives to cooperate within counties where municipalities are of small dimension could help to achieve lower costs and improved efficiency. Yet, this potential is not unconditional. Local services need to be characterized by the existence of scale economies. Thus, we want to stress that the municipalities that cooperate need to have fairly small population thresholds, since larger municipalities already tend to be operating at an optimal scale. In this context, if there are economies of scale to be exploited and if municipalities are small, cooperation can be well worth promoting. 


\section{REFERENCES}

Agranoff, Robert. 2010. Local Governments and Their Intergovernmental Networks in Federalizing Spain. Montreal \& Kingston: McGill-Queen's University Press.

Allers, Maarten A. and J. Bieuwe Geertsema 2012. Do municipal amalgamations affect local government spending and taxation? Evidence from the Netherlands. Paper presented at the 2012 Conference of the Public Choice Society. http://www.pubchoicesoc.org/papers_2012/Allers_Geertsema.pdf (accessed September 3, 2012)

Ballard, Michael J. and Mildred Warner. 2000. Taking the high road: Local government restructuring and the quest for quality. In AFSCME (ed.), Power Tools for Fighting Privatization, Washington DC: American Federation of State, County and Municipal Employees, 6/1-6/53.

Bel, Germà. 2006. Economía y política de la privatización local, Marcial Pons, Madrid.

Bel, Germà. Forthcoming. Local Government Size and Efficiency in Capital Intensive Services: What Evidence is There of Economies of Scale, Density and Scope?. In Santiago Lago-Peñas and Jorge Martinez-Vazquez, eds. The Challenge of Local Government Size. Theoretical Perspectives, International Experience, and Policy Reform. Edward Elgar, Cheltenham, forthcoming.

Bel, Germà and Antón Costas. 2006. Do public sector reforms get rusty?: Local privatization in Spain. Journal of Policy Reform, 9(1): 1-24.

Bel, Germà, Elbert Dijkgraaf, Xavier Fageda and Raymond Gradus. 2010. Similar problems, different solutions: Comparing refuse collection in the Netherlands and Spain. Public Administration, 88(2), 479-495.

Bel, Germà and Xavier Fageda. 2007. Why do local governments privatise local services? A survey of empirical studies. Local Government Studie 33(4): 517-534.

Bel, Germà and Xavier Fageda. 2008. Reforming the local public sector: Economics and politics in privatization of water and solid waste. Journal of Economic Policy Reform 11(1), 45-65.

Bel, Germà and Xavier Fageda. 2009. Factors explaining local privatization: a meta-regression analysis. Public Choice 139 (1/2): 105-119.

Bel, Germà and Xavier Fageda. 2010. Empirical analysis of solid management waste costs: Some evidence from Galicia, Spain. Resources, Conservation and Recycling 54 (1): 187-193.

Bel, Germà and Xavier Fageda. 2011. Big Guys Eat Big Cakes: Firm Size and Contracting In Urban and Rural Areas. International Public Management Journal 14 (1), 4-26.

Bel, Germà, Xavier Fageda and Mildred Warner. 2010. Is Private Production of Public Services Cheaper than Public Production? A meta-regression analysis of solid waste and water services. Journal of Policy Analysis and Management 29 (3): 553-577.

Bel, Germà and Antonio Miralles. 2003. Factors influencing the privatisation of urban solid waste collection in Spain. Urban Studies 40(7): 1323-1334

Bel, Germà and Melania Mur. 2009. Inter-municipal cooperation, privatization and waste management costs: Evidence from rural municipalities. Waste Management 29 (10): 2772-2778.

Bel, Germà and Mildred Warner. 2008a. Does privatization of solid waste and water services reduce costs? A review of empirical studies. Resources, Conservation \& Recycling, 52(12): 1337-1348.

Bel, Germà and Mildred Warner. 2008b. Challenging issues in local privatization. Environment and Planning C: Government \& Policy, 26 (1): 104-109.

Brown, Trevor L. 2008. The Dynamics of Government-to-Government Contracts. Public Performance Management Review 31(3):364-386. 
Brown, Trevor L. and Matthew Potoski. 2003a. Transaction costs and institutional explanations for government service production decisions. Journal of Public Administration Research and Theory 13 (4): 441-468.

Brown, Trevor L. and Matthew Potoski. 2003b. Managing contract performance: A transaction cost approach. Journal of Policy Analysis and Management, 22 (2): 275-297.

Brown, Trevor L. and Matthew Potoski. 2005. Transaction Costs and Contracting: The Practitioner Perspective. Public Performance and Management Review 28(3): 326-351.

Callan, S Scott J. and Janet M. Thomas. 2001. Economies of scale and scope: A cost analysis of municipal solid waste services. Land Economics 77(3): 548-560.

Carr, Jered B., Kelly LeRoux and Manoj K. Shrestha. 2009. Institutional Ties, Transaction Costs, and External Service Production. Urban Affairs Review, 44(3): 403-27.

Dijkgraaf, Elbert and R.H.J.M. Gradus.2003. Cost savings of contracting out refuse collection”, Empirica 30 (2): 149-161.

Dixit, Avinash 1973. The optimum factory town. Bell Journal of Economics and Management Science 4(2): 637-651.

Domberger. Simon, Shirley A. Meadowcroft y David J. Thompson. 1986. Competitive tendering and efficiency: The case of refuse collection. Fiscal Studies 7(4): 69-87.

Donahue, John. 1989. The privatization decision: Private means for public ends. Basic Books, New York.

Dubin, Jeffrey A. and Peter Navarro. 1988. How markets for impure public goods organize: the case of household refuse collection. Journal of Law, Economics and Organization 4(2): 217-241.

Emerson, Kirk, Tina Nabatchi and Stephen Balogh. 2012. An Integrative Framework for Collaborative Governance. Journal of Public Administration Research and Theory 22(1): 1-29.

Feiock, Richard C. 2007. Rational Choice and Regional Governance, Journal of Urban Affairs 29 (1): 47-63.

Feiock, Richard C. and John T. Scholz. eds. 2010, Self-organizing federalism: Collaborative mechanisms to mitigate institutional collective action. Cambridge University Press, Cambridge.

Fluvià, Modest, Ricard Rigall i Torrent and Anna Garriga. 2008. Déficit en la provisión local de servicios públicos y tipología municipal. Revista de Economía Aplicada 16(48): 111-132.

Frederickson, H. George and Kevin B. Smith. 2003.The Public Administration Theory Primer. Westview, Boulder CO

Garrone, Paola, Luca Grilli and Xavier Rousseau. forthcoming. Management Discretion and Political Interference in Municipal Enterprises. Evidence from Italian Utilities. Local Government Studies, forthcoming.

Hefetz, Amir and Mildred E. Warner. 2004. Privatization and Its Reverse: Explaining the Dynamics of the Government Contracting Process. Journal of Public Administration, Research and Theory 14(2):171-190.

Hefetz, Amir and Mildred E. Warner 2012. Contracting or Public Delivery? The importance of service, market and management characteristics. Journal of Public Administration Research and Theory 22(2): 289-317.

Hefetz, Amir, Mildred Warner and Eran Vigoda-Gadot (2012). Privatization and inter-municipal contracting: The US local government experience 1992-2007. Environment and Planning C: Government and Policy 30(4):675-692.

Hirsch, Werner Z. 1965. Cost functions of an urban government service: refuse collection. Review of Economics and Statistics 47 (1), 87-92. 
Holzer, Marc and John Fry. 2011. Shared services and municipal consolidation. A critical analysis. Public Technology Institute, Alexandria (VA).

Hulst, Rudie and André van Montfort, eds. 2007. Inter-Municipal Cooperation in Europe. Springer, Dordrecht.

Kelly, Josephine. 2007. The curious absence of inter-municipal cooperation in England. Public Policy and Administration, 22(3): 319-334.

Kemper, Peter and John Quigley. 1976. The Economics of Refuse Collection. Ballinger, Cambridge (MA).

Kitchen, Harry M. 1976. A statistical estimation of an operating cost function for municipal refuse collection. Public Finance Quarterly 4(1): 56-76.

Lago-Peñas, Santiago and Jorge Martinez-Vazquez, eds. The Challenge of Local Government Size. Theoretical Perspectives, International Experience, and Policy Reform. Edward Elgar, Cheltenham, forthcoming.

Lamothe, Meeyoung and Scott Lamothe. Forthcoming. To Trust or Not to Trust? What Matters in Local Government-Vendor Relationships? Journal of Public Administration Research and Theory, forthcoming.

Lamothe, Scott, Meeyoung Lamothe and Richard C. Feiock. 2008. Examining Local Government Service Delivery Arrangements Over Time. Urban Affairs Review 44(1): 27-56.

LeRoux, Kelly, Paul W. Brandenburger and Sanjay K. Pandey. 2010. Interlocal Service Cooperation in US Cities: A Social Network Explanation. Public Administration Review, 70(2): 268-278.

LeRoux, Kelly and Jered B. Carr. 2007. Explaining Local Government Cooperation on Public Works: Evidence from Michigan. Public Works Management and Policy, 12(1): 344-58.

Levin, Jonathan and Steven Tadelis. 2010. Contracting for government services: theory and evidence from U.S. cities. Journal of Industrial Economics LVIII (3): 507-541.

Lowery, David. 2000. A Transactions Costs Model of Metropolitan Governance: Allocation Versus Redistribution in Urban America. Journal of Public Administration Research and Theory 10(1): 4978.

Milward, H. B., and Keith G. Provan. 2000. Governing the hollow state. Journal of Public Administration Research and Theory 10 (2): 359-79.

Mirrless, James A. 1972. The optimum town. Swedish Journal of Economics 74(1): 114-135.

Oates, Wallace, 1972. Fiscal Federalism. Harcourt Brace Jovanovich, New York.

Ostrom, Vincent, Charles M. Tiebout, and Robert Warren 1961. The organization of government in metropolitan areas: A theoretical inquiry. American Political Science Review 55 (4): 831-842.

Pier, William J., Robert B. Vernon and John H. Wicks. 1974. An empirical comparison of government and private production efficiency. National Tax Journal 27 (4): 653-656.

Reeves, Eoin and Michael Barrow. 2000. The impact of contracting-out on the costs of refuse collection services. The case of Ireland. Economic and Social Review 31(2): 129-150.

Shrestha, Manoj. K. and Richard C. Feiock. 2011. Transaction Cost, Exchange Embeddedness, and Interlocal Cooperation in Local Public Goods. Political Research Quarterly, 64 (3): 573-587.

Sørensen, Rune J. 2007. Does Dispersed Public Ownership Impair Efficiency? The Case of Refuse Collection in Norway. Public Administration, 85(4): 1045-58.

Steiner, Reto. 2003. The causes, spread and effects of inter-municipal cooperation and municipal mergers in Switzerland. Public Management Review 5(4): 551-571. 
Stevens, Barbara J. 1978. Scale, market structure, and the cost of refuse collection. Review of Economics and Statistics, 60(3): 438-448.

Swianiewicz, Pawel, eds. 2011. Working Together. Inter-municipal Cooperation in Five Central European Countries. Open Society Institute, Budapest.

Szymanski, Stefan and Sean Wilkins. 1993. Cheap rubbish? Competitive tendering on refuse collection services. Fiscal Studies 14(3): 109-130.

Warner, Mildred. 2006. Market-based governance and the challenge for rural governments: US trends. Social Policy \& Administration 40 (6): 612-631.

Warner, Mildred E. and Germà Bel. 2008. Competition or Monopoly? Comparing Privatization of Local Public Services in the U.S. and Spain. Public Administration 86 (3): 723-735.

Warner, Mildred E. and Robert Hebdon. 2001. Local government restructuring: privatization and its alternatives. Journal of Policy Analysis and Management 20(2): 315-336.

Warner, Mildred E. and Amir Hefetz. 2002. Applying Market Solutions to Public Services: An Assessment of Efficiency, Equity and Voice. Urban Affairs Review 38(1):70-89.

Warner, Mildred. and Amir Hefetz. 2003. Rural-urban differences in privatization: limits to the competitive state. Environment and Planning C: Government and Policy 21 (5): 703-718.

Williamson, Oliver E. 1991. Comparative economic organization: The analysis of discrete structural alternatives. Administrative Science Quarterly, 36 (2), 269-296.

Zafra-Gómez, Jose Luis, Diego Prior, Ana Maria Plata Díaz and Antonio M. López-Hernández (forthcoming): "Reducing costs in times of crisis: Delivery forms in small and medium sized local governments' waste management services", Public Administration, forthcoming 


\section{APPENDIX}

Table A1. Characteristics of the municipalities that cooperate

\begin{tabular}{|c|c|c|c|}
\hline Municipality & County & $\begin{array}{l}\text { Population } \\
\text { (number of } \\
\text { inhabitants }\end{array}$ & $\begin{array}{l}\text { Distance to the capital of } \\
\text { the county (kilometers) }\end{array}$ \\
\hline Biescas & C. Alto Gallego & 1712 & 15 \\
\hline Sabiñanigo & C. Alto Gallego & 10112 & 0 \\
\hline Sallent de Gallego & C. Alto Gallego & 1376 & 34 \\
\hline Alcorisa & C. Bajo Aragón & 3692 & 37 \\
\hline Calanda & C. Bajo Aragón & 3825 & 22 \\
\hline Mas de las Matas & C. Bajo Aragón & 1445 & 41 \\
\hline Belver & C. Bajo Cinca & 1380 & 24 \\
\hline Fraga & C. Bajo Cinca & 14034 & 0 \\
\hline Mequinenza & C. Bajo Cinca & 2478 & 20 \\
\hline Albalate del Arzobispo & C. Bajo Martín & 2233 & 11 \\
\hline Hijar & C. Bajo Martín & 1928 & 0 \\
\hline Puebla de Hijar, La & C. Bajo Martín & 1018 & 7 \\
\hline Ainzon & C. Campo de Borja & 1274 & 3 \\
\hline Borja & C. Campo de Borja & 4838 & 0 \\
\hline Fuendejalón & C. Campo de Borja & 1034 & 14 \\
\hline Magallón & C. Campo de Borja & 1221 & 9.5 \\
\hline Mallen & C. Campo de Borja & 3680 & 21 \\
\hline Albalate de Cinca & C. Cinca Medio & 1179 & 30 \\
\hline Binaced & C. Cinca Medio & 1534 & 10 \\
\hline Monzón & C. Cinca Medio & 16749 & 0 \\
\hline Biota & C. Cinco Villas & 1138 & 21 \\
\hline Ejea de los Caballeros & C. Cinco Villas & 17178 & 0 \\
\hline Sádaba & C. Cinco Villas & 1696 & 22 \\
\hline Tauste & C. Cinco Villas & 7690 & 28 \\
\hline Almudévar & C. Hoya de Huesca & 2449 & 21 \\
\hline Ayerbe & C. Hoya de Huesca & 1126 & 29 \\
\hline Gurrea de Gallego & C. Hoya de Huesca & 1710 & 39 \\
\hline Huesca & C. Hoya de Huesca & 51117 & 0 \\
\hline Sotonera, La & C. Hoya de Huesca & 1058 & 21 \\
\hline Altorricón & C. La Litera & 1491 & 18 \\
\hline Binéfar & C. La Litera & 9288 & 0 \\
\hline Tamarite de Litera & C. La Litera & 3715 & 12 \\
\hline Bujaraloz & C. Monegros & 1048 & 40 \\
\hline Grañen & C. Monegros & 2041 & 28 \\
\hline Lalueza & C. Monegros & 1137 & 12 \\
\hline Lanaja & C. Monegros & 1478 & 17 \\
\hline Leciñena & C. Monegros & 1309 & 44 \\
\hline Sariñena & C. Monegros & 4308 & 0 \\
\hline
\end{tabular}




\begin{tabular}{|c|c|c|c|}
\hline Tardienta & C. Monegros & 1043 & 44 \\
\hline Alagón & C. Ribera Alta del Ebro & 6894 & 0 \\
\hline Gallur & C. Ribera Alta del Ebro & 3004 & 25 \\
\hline Luceni & C. Ribera Alta del Ebro & 1080 & 18 \\
\hline Pedrola & C. Ribera Alta del Ebro & 3488 & 11 \\
\hline Pinseque & C. Ribera Alta del Ebro & 3252 & 6.5 \\
\hline Remolinos & C. Ribera Alta del Ebro & 1198 & 9.5 \\
\hline Torres de Berrellen & C. Ribera Alta del Ebro & 1517 & 10 \\
\hline Gelsa & C. Ribera Baja del Ebro & 1207 & 5 \\
\hline Pina de Ebro & C. Ribera Baja del Ebro & 2552 & 13 \\
\hline Quinto & C. Ribera Baja del Ebro & 2101 & 0 \\
\hline Almunia de Doña & C. Valdejalón & 7633 & 0 \\
\hline Godina & C. Valdejalón & 3024 & 9.5 \\
\hline Calatorao & C. Valdejalón & 4682 & 19 \\
\hline Epila & C. Valdejalón & 1053 & 23 \\
\hline Lumpiaque & C. Valdejalón & 1354 & 5 \\
\hline Morata de Jalón & C. Valdejalón & 3400 & 7.5 \\
\hline Ricla & Mancomunidad Bajo Gallego & 2895 & 16 \\
\hline San Mateo de Gállego & Mancomunidad Bajo Gallego & 4101 & 0 \\
\hline Villanueva de Gállego & Mancomunidad Bajo Gallego & 7288 & \\
\hline Zuera & & & \\
\hline
\end{tabular}

Note: We only show counties where more than two municipalities in our sample cooperate in the delivery of solid waste 